\title{
The Purity of the Cobalt Phase in Cemented Carbide Hard Alloys*
}

\author{
By Atsushi Nishiyama** and Ryuichi Ishida**
}

\begin{abstract}
The cobalt phase purity in hard alloys was examined by the X-ray diffraction method and the Curie point was measured. It was found that fairly large amounts of various atoms could be dissolved in cobalt and that the purity at high temperature depended largely upon the alloy carbon content.
\end{abstract}

(Received March 12, 1961)

\section{Introduction}

The sintering mechanism of cemented carbide has been reported by many investigators and presently it is believed that the liquid phase is formed at the sintering temperature where carbides are dissolved in cobalt. When the carbon content is somewhat less than that theoretically desired for the amount of carbides present, the $\delta$ phase appears during cooling from the sintering temperature down to $1300^{\circ}$ to $1350^{\circ} \mathrm{C}$, below which carbides and excess free carbon precipitate.

Pfau and Rix ${ }^{(1)}$ have reported that the quantity of WC in solid cobalt in sintered and quenched WC-Co specimens led them to the following conclusions:

1. WC is dissolved in solid cobalt, not as a molecule, but $\mathrm{W}$ and $\mathrm{C}$ atoms are dissolved independently.

2. When free $W C$ remains, the $W$ and $C$ atoms precipitate very easily on cooling, as the free $\mathrm{WC}$ acts as a kernel for precipitation.

3. The cobalt phase in W-Co hard alloy, because of its low cobalt content, can be considered to have a high purity; but cobalt in a W-TiC-Co alloy which corresponds to a WC-Co alloy of lower WC content, (as the exterior surface of WC is reduced very strongly by the mixed carbide) is probably of low purity.

The authors examined the cobalt phase purity in a hard alloy, measuring the lattice parameter of the face-centered cubic cobalt phase by X-ray spectrometer and measuring the Curie point of the cobalt phase using an automatic-recording magnetic balance, and reached some conclusions considerably different from those widely accepted.

\section{Preparation of Specimens}

Vacuum melted cobalt alloys and commercial hard alloys were used for specimens. A vacuum furnace, type MA 3502, manufactured by the Nihon Vacuum Company of Japan was used to melt all of the cobalt alloys. This vacuum furnace has a Mo plate heating element and both a rotary oil pump and an oil diffusion pump are used.

* This paper was presented at the meetings of the Japan Institute of Metals, October 1958 Nagoya, Japan and April 1959, Tokyo, Japan.

** Sumitomo Electric Industries, Ltd., Itami, Hyogo Prefecture, Japan

(1) H. Pfau and W. Rix : Abhandlung Der Osram Gesellschaft Bd, 6(1953), S.193/201.

Trans. J I M
W $(\mathrm{Fe}: 0.013 \% ; \mathrm{Ni}<10 \mu)$, WC $(\mathrm{Fe}: 0.12 \% ; \mathrm{Ni}<$ $10 \mu)$, active carbon and $\mathrm{TiC}(\mathrm{Fe}: 0.013 \% ; \mathrm{Ni}<10 \mu)$ were added as required to cobalt $(\mathrm{Fe}: 0.014 \%$; $\mathrm{Ni}<$ $10 \mu)$ and blended manually. About 300 grams of the mixtures were put into an alumina crucible and the crucible containing the mixture was placed inside the furnace.

The temperature was measured with an optical pyrometer and the temperature was increased from room temperature to the predetermined temperature in about two hours, maintaining the atmospheric pressure below $5 \mu$ of Mercury. The temperature was maintained for about 40 minutes slightly higher than the

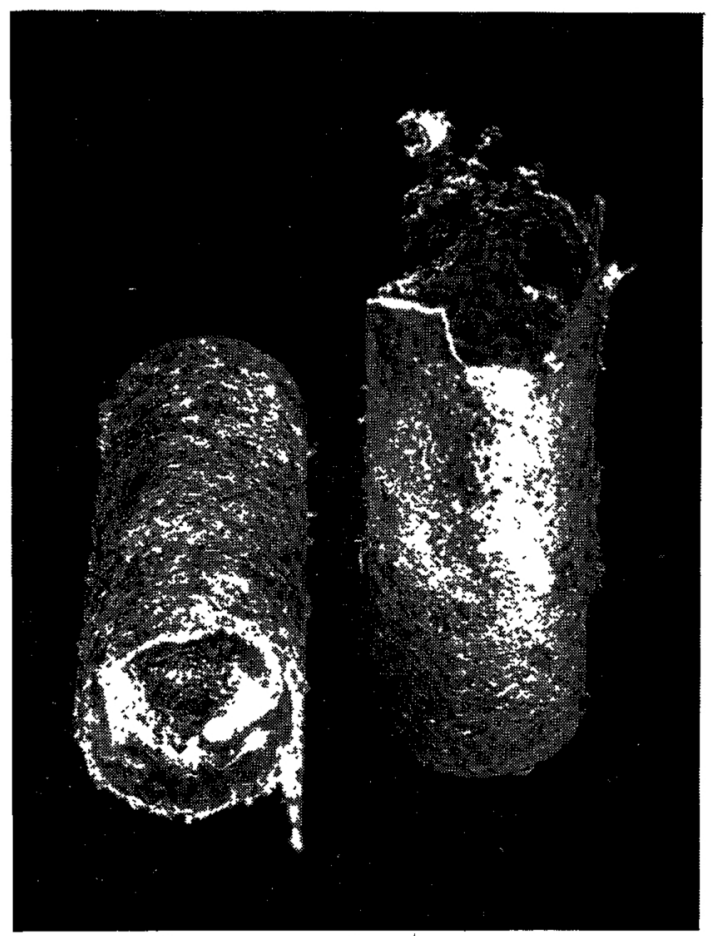

Photo. 1 Outside viéw of ingot.

melting point of the mixture after which the melt was cast into steel molds in the furnace cold zone. Photo. 1 shows the appearance of the outside of a typical ingot. The chemical compositions of the alloys used are shown in Table 1.

Determination of the alloys solvent cobalt phase and free carbon if any was made by observation of their microstructures and identification of the X-ray diffraction patterns. Phase crystal structure was either facecentered cubic, hexagonal-close packed or a mixture of

1962 Vol. 3 
both of them.

For cemented carbide specimens, various commercial hard alloys produced in Japan or imported, specially prepared alloys prepared by our company as well as alloys of inferior quality were used. All the specimens

Table 1 The chemical compositions of Co ingots determined chemically and physically.

\begin{tabular}{|c|c|c|c|c|c|c|}
\hline \multirow[b]{2}{*}{$\begin{array}{c}\text { Ingot } \\
\text { No. }\end{array}$} & \multicolumn{5}{|c|}{ Chemical components (wt \%) } & \multirow[b]{2}{*}{$\begin{array}{l}\text { Precipitate } \\
\text { existence }\end{array}$} \\
\hline & $\mathrm{Ti}$ & W & $\begin{array}{l}\text { Free } \\
\text { carbon }\end{array}$ & $\begin{array}{l}\text { Total } \\
\text { carbon }\end{array}$ & $\begin{array}{c}\text { Combined } \\
\text { carbon }\end{array}$ & \\
\hline 1 & 3.94 & 2.19 & 1.96 & 3.03 & 1.07 & $\begin{array}{l}\text { precipitate } \\
\text { noticed }\end{array}$ \\
\hline $\begin{array}{l}2 \\
3 \\
4 \\
5 \\
6\end{array}$ & $\begin{array}{l}4.74 \\
7.74 \\
1.93 \\
2.43 \\
4.48\end{array}$ & $\begin{array}{r}2.16 \\
3.88 \\
6.05 \\
8.97 \\
11.79\end{array}$ & $\begin{array}{l}0.93 \\
2.15 \\
0.84 \\
0.99 \\
2.19\end{array}$ & $\begin{array}{l}2.39 \\
4.21 \\
1.75 \\
2.05 \\
3.68\end{array}$ & $\begin{array}{l}1.46 \\
2.26 \\
0.91 \\
1.06 \\
1.49\end{array}$ & $\begin{array}{l}\text { " } \\
" 1 \\
" 1\end{array}$ \\
\hline 7 & 2.00 & - & 0.20 & 0.21 & 0.01 & $\begin{array}{l}\text { no } \\
\text { precipitate }\end{array}$ \\
\hline $\begin{array}{r}8 \\
9 \\
10\end{array}$ & $\begin{array}{r}5.10 \\
12.90 \\
15.90\end{array}$ & - & $\begin{array}{l}0.57 \\
0.85 \\
1.60\end{array}$ & $\begin{array}{l}0.58 \\
0.86 \\
1.61\end{array}$ & $\begin{array}{l}0.01 \\
0.01 \\
0.01\end{array}$ & $\begin{array}{c}\text { noticed } \\
" 1 \\
"\end{array}$ \\
\hline 11 & 一 & 13.81 & 一 & - & 一 & $\begin{array}{l}\text { no } \\
\text { precipitate }\end{array}$ \\
\hline $\begin{array}{l}12 \\
13 \\
14\end{array}$ & - & $\begin{array}{l}7.72 \\
2.96 \\
2.10\end{array}$ & - & - & - & $\begin{array}{l}\text { " } \\
\text { " }\end{array}$ \\
\hline 15 & 一 & - & 0.0033 & 0.05 & 0.047 & " \\
\hline 16 & - & - & 1.72 & 2.02 & 0.30 & " \\
\hline 17 & 一 & 8.91 & 0.01 & 0.32 & 0.31 & " \\
\hline 18 & - & 15.98 & 0.06 & 0.80 & 0.74 & $\begin{array}{l}\text { precipitate } \\
\text { noticed }\end{array}$ \\
\hline 19 & 一 & 4.98 & 0 & 0.04 & 0.04 & $\begin{array}{l}\text { no } \\
\text { precipitate }\end{array}$ \\
\hline 20 & 一 & 2.70 & 0 & 0.16 & 0.16 & "1 \\
\hline
\end{tabular}

contained between 5 to $25 \%$ cobalt, because cobalt is the only satisfactory cementing metal for WC or a combination of $\mathrm{WC}$ with $\mathrm{TiC}$ and $\mathrm{Ta}(\mathrm{Nb}) \mathrm{C}$. Microstructure, hardness, density, strength and other properties were measured and the resulting values varied over a wide range.

\section{Experimental Procedures}

\section{Determination of the lattice parameter}

An X-ray spectrometer, manufactured by the Rigaku Electric Company of Japan, which has a Geiger and Müller counter for X-ray detection was used. Measuring conditions were as follows: Fe-ray, $40 \mathrm{KV}$, divergence slit $4^{\circ}$, counter slit $0.4 \mathrm{~mm}$, scanning speed $1 / 4^{\circ}$ per minute.

Spacing of the (311) plane of the face-centered cubic cobalt phase was measured and the accuracy of the calculated parameter was $\pm 0.001 \AA$. A few diffraction patterns are shown in Fig. 1. Flat rectangular surfaces $1 \mathrm{~cm}^{2}$ which had been ground and treated chemically were used.

Cobalt alloys were etched with concentrated nitric acid for three minutes and the hard alloy carbide phases were etched electrolytically as follows:

1. WC-Co: in a $10 \%$ solution of sodium carbonate using a current density of $1 \mathrm{~A} / \mathrm{cm}^{2}$ for 20 minutes.

2. WC-TiC-Co : in a $10 \%$ solution of sodium carbonate and $5 \%$ potassium sodium tartrate (Rochelle Salt) using a current density of $0.8 \mathrm{~A} / \mathrm{cm}^{2}$ for two hours.

3. WC-TiC-Ta (Nb) C-Co: in a $10 \%$ solution of sodium carbonate and a $5 \%$ solution of potassium sodium tartrate (Rochelle Salt) and then in a 10 $\%$ solution of potassium ferricyanide using a current density of $0.8 \mathrm{~A} / \mathrm{cm}^{2}$ for thirty minutes.

\section{Determination of the Curie point}

An automatic-recording magnetic balance designed

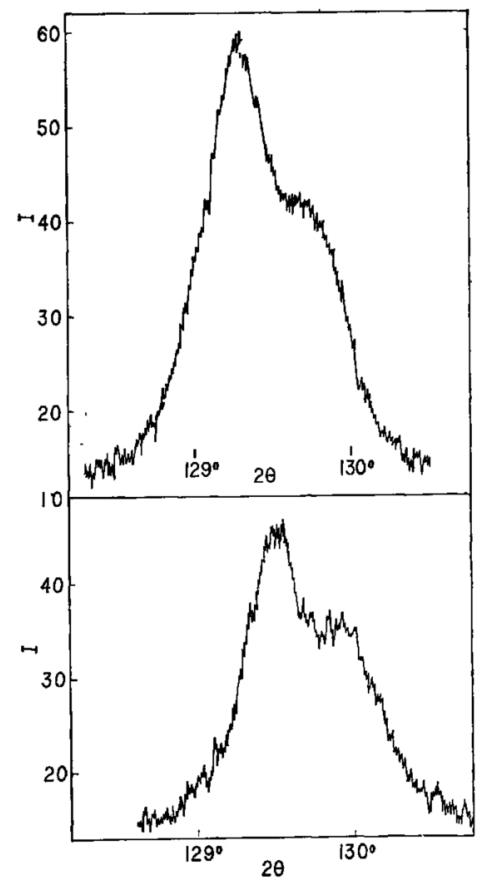

Fig. 1 Examples of diffraction pattern. (311) plane of cobalt

by Professor T. Hirone ${ }^{(2)}$, Professor N. Tsuya and Dr. S. Maeda and manufactured by the Naruse Scientific Machine Company of Japan was used to determine the Curie point. 0.1 to 0.5 gram specimens were sealed

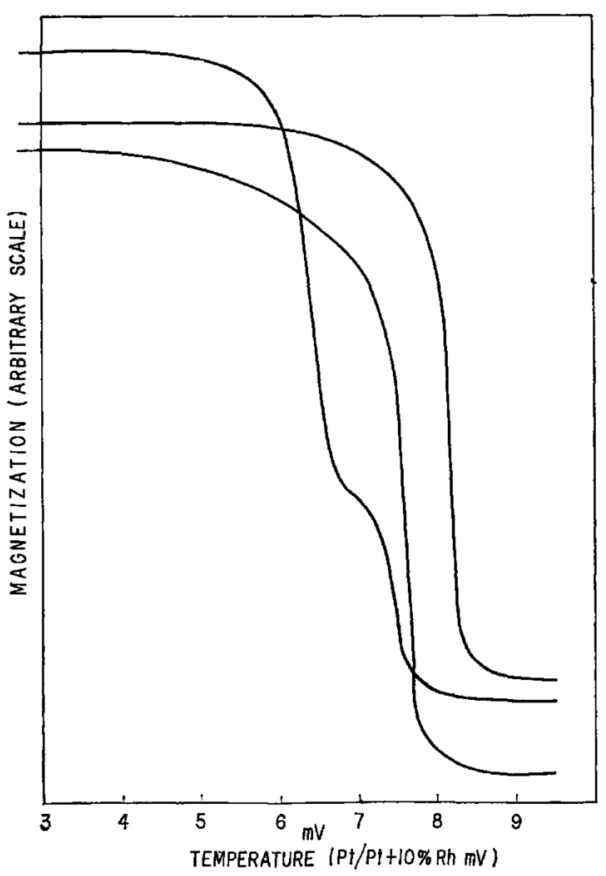

Fig. 2 Magnezation-temperature curve.

in evacuted silica capusules.

A force of $<10 \mathrm{mg}$ acting on the specimens in the

(2) Tokutaro Hirone, Noboru Tsuya and Seijiro Maeda : Review of Scientific Instruments, 25 (1954), 516. 
magnetic field of the order of a several hundred Oerstead was recorded automatically with an $X-Y$ recorder which also recorded the temperature of the specimens.

The temperature was measured with a platinumplutinum rhodium thermocouple and the heating and cooling rate was $100^{\circ} \mathrm{C}$ per minute.

Magnetization-temperature curves during a typical run are shown in Fig. 2. The Curie points were presumed conclusively to coincide with the inflection point on the magnetization-temperature, examples of which are shown in Fig. 3. Temperature measurements were maintained within $\pm 5^{\circ} \mathrm{C}$, but Curie point reproducibility was of the order of $\pm 10^{\circ} \mathrm{C}$.

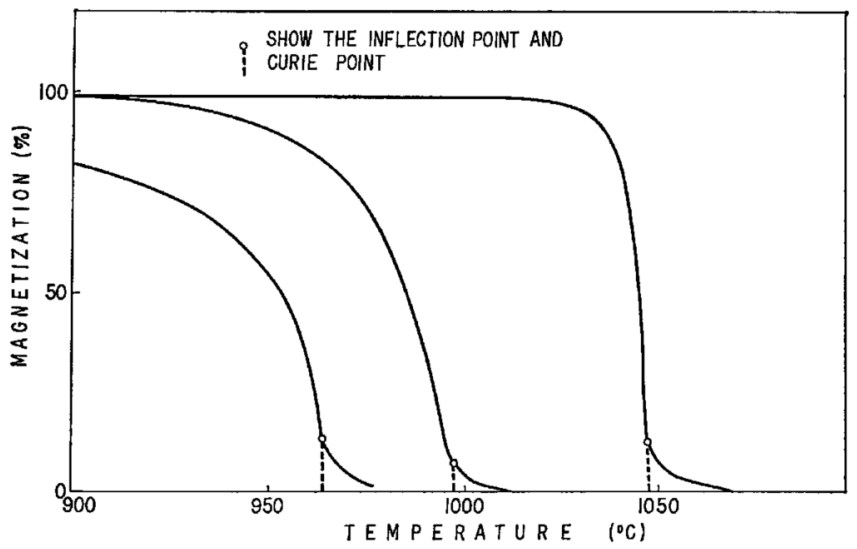

Fig. 3 Determination of curie point from the magnetization-temperature curve.

\section{Experimental Results}

\section{Cobalt alloys}

Cobalt alloys results are summarized in Table 2 and shown in Fig. 4 and Fig. 5 together with previously

Table 2 Lattice parameters and curie points of cast cobalt alloys.

\begin{tabular}{|c|c|c|c|}
\hline $\begin{array}{c}\text { Ingot } \\
\text { No. }\end{array}$ & $\underset{\text { structure* }}{\text { Crystal }}$ & $\begin{array}{c}\text { Lattice parameter of } \\
\text { face-centred cubic } \\
\text { cobalt }(\AA)\end{array}$ & $\begin{array}{l}\text { Curie } \\
\text { point } \\
\left({ }^{\circ} \mathrm{C}\right)\end{array}$ \\
\hline $\begin{array}{r}1 \\
2 \\
3 \\
4 \\
5 \\
6 \\
7 \\
8 \\
9 \\
10 \\
11 \\
12 \\
13 \\
14 \\
15 \\
16 \\
17 \\
18 \\
19 \\
20\end{array}$ & $\begin{array}{c}\mathbf{H} \\
\mathbf{H} \\
\mathbf{H} \\
\mathbf{C} \\
\mathbf{H} \\
\mathbf{H} \\
\mathbf{C} \\
\mathbf{H} \\
\mathbf{C} \\
\mathbf{C} \\
\mathbf{C} \\
\mathbf{H} \\
\mathbf{H} \\
\mathbf{H} \\
\mathbf{C} \\
\mathbf{C} \\
\mathbf{C} \\
\mathbf{C} \\
\mathbf{H} \\
\mathbf{H}\end{array}$ & $\begin{array}{l}3.5629 \\
3.5455 \\
3.5528 \\
3.5498 \\
3.5876 \\
\\
\\
3.5433 \\
3.5513 \\
3.5669 \\
3.5863\end{array}$ & $\begin{array}{r}1068 \\
1030 \\
944 \\
1042 \\
972 \\
1000 \\
1062 \\
1005 \\
875 \\
947 \\
830 \\
975 \\
1056 \\
1067 \\
1047 \\
1044 \\
988 \\
834 \\
1019 \\
1050\end{array}$ \\
\hline
\end{tabular}

*H : Hexagonal closed packed

C : Face-centred cubic

published data. The author's results will be used hereinafter as tentative standards for the estimation of the quantities of solute atoms in the cobalt phase of hard alloys. Lattices were face-centered cubic or hexagonal-close packed, or a mixture of both.

\section{Hard alloys}

Some results of the cobalt phase in W-Co hard alloys are shown in Table 3, together with the presumptive quantities of solute atoms roughly estimated both by lattice parameter and Curie temperature. No mutual relations between the quantities from the lattice para-

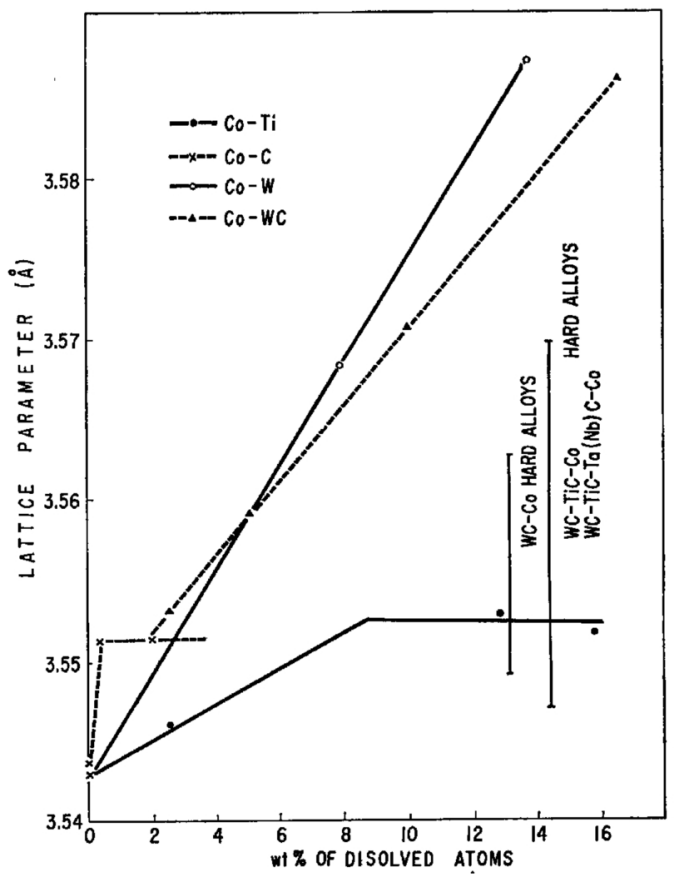

Fig. 4 Relations between the amount of dissolved atoms and lattice parameter of cobalt alloys.

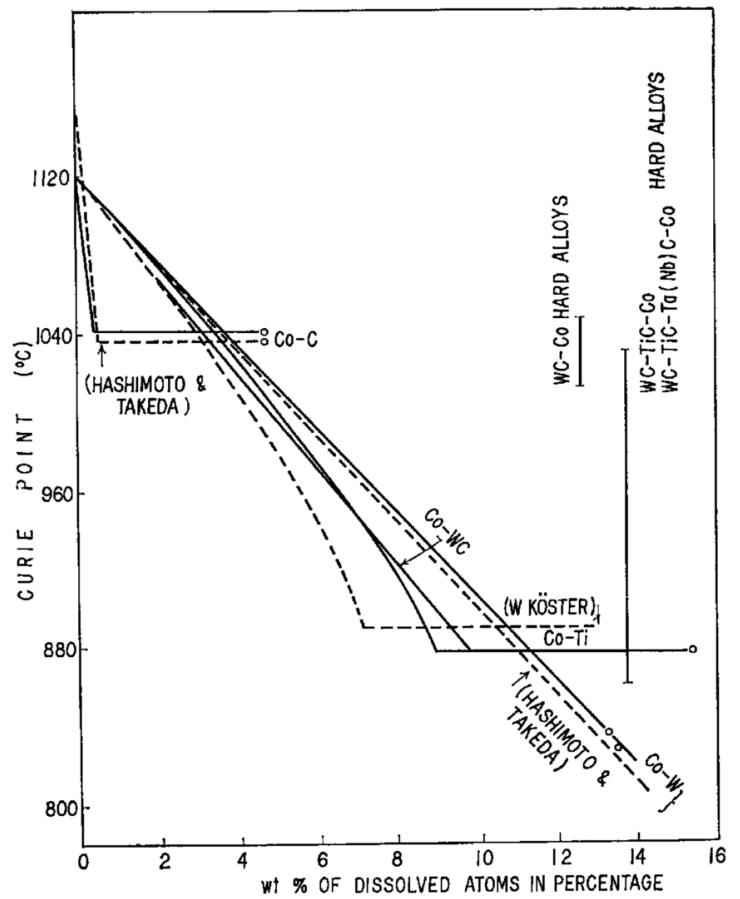

Fig. 5 Relations between the amount of dissolved atoms and the curie point of cobalt alloys.

meter and Curie point could be deduced.

Some alloys showed qvery large quantities of solute and they were as large as $15 \%$. Effects of heattreatment upon the cobalt phase were next investigated in an effort to discover the reason for the disparity mentioned above and the results are shown in Table 4. As shown in Table 4 the cobalt phase in all hard 
Table 3 Results of WC-Co hard alloys

\begin{tabular}{|c|c|c|c|c|c|c|}
\hline \multirow{2}{*}{$\begin{array}{l}\text { Specimen } \\
\text { No. }\end{array}$} & \multirow{2}{*}{$\begin{array}{c}\mathrm{Co} \\
\text { (wt \%) }\end{array}$} & \multirow{2}{*}{$\begin{array}{c}\text { Lattice } \\
\text { parameter } \\
(\AA)\end{array}$} & \multirow{2}{*}{$\begin{array}{l}\text { Curie } \\
\text { point } \\
\left({ }^{\circ} \mathrm{C}\right)\end{array}$} & \multicolumn{2}{|c|}{$\begin{array}{l}\text { Estimated amount of } \\
\text { dissolved W.C (wt \%) }\end{array}$} & \multirow{2}{*}{ Remarks } \\
\hline & & & & $\begin{array}{l}\text { By latiice } \\
\text { parameter }\end{array}$ & $\begin{array}{c}\text { By curie } \\
\text { point }\end{array}$ & \\
\hline 1 & 5 & \multirow{15}{*}{$\begin{array}{ll} & 3.5571 \\
\text { (1) } & 3.5759 \\
\text { (2) } & 3.5700 \\
& 3.5491 \\
& 3.5569 \\
& 3.5540 \\
& 3.5506 \\
& 3.5520 \\
& 3.5624 \\
3.5491 \\
& 3.5515 \\
& 3.5503 \\
& 3.5535 \\
& 3.5537 \\
& 3.5491 \\
& 3.5491\end{array}$} & 947 & \multirow{15}{*}{ (1) $\begin{array}{r}4 \\
\text { (2) } \\
9 \\
2 \\
4 \\
4 \\
3 \\
3 \\
3 \\
3 \\
4 \\
2 \\
3 \\
2 \\
3 \\
3 \\
3 \\
2 \\
3\end{array}$} & 10 & $\delta$ phase noticed \\
\hline 2 & 5 & & 883 & & 14 & $"$ \\
\hline 3 & 5 & & 967 & & 9 & " \\
\hline 4 & 5 & & 1010 & & 6 & superior quality \\
\hline 5 & 5 & & 1015 & & 6 & "1 \\
\hline 6 & 7 & & 1016 & & 6 & fairly laige amount of free carbon \\
\hline 7 & 10 & & 1042 & & 4 & " \\
\hline 8 & 12 & & 1013 & & 6 & superior quality \\
\hline 9 & 12 & & 1067 & & 2 & " \\
\hline 10 & 12 & & 1005 & & 7 & " \\
\hline 11 & 12 & & 1024 & & 5 & $"$ \\
\hline 12 & 12 & & 1027 & & 5 & $"$ \\
\hline 13 & 12 & & 1032 & & 4 & " \\
\hline 14 & 12 & & 1010 & & 6 & ditto, coarse grains of WC \\
\hline 15 & 25 & & 1067 & & 4 & low quality, fair amount of $\delta$ phase \\
\hline
\end{tabular}

Table 4 Effects of heat treatment on the properies of the cobalt phase in WC-Co hard alloys.

\begin{tabular}{|c|c|c|c|c|c|}
\hline \multirow{2}{*}{$\begin{array}{l}\text { Specimen } \\
\text { No. }\end{array}$} & \multirow{2}{*}{$\begin{array}{c}\text { Lattice } \\
\text { parameter } \\
(\AA)\end{array}$} & \multirow{2}{*}{$\begin{array}{l}\text { Curie } \\
\text { point } \\
\left({ }^{\circ} \mathrm{C}\right)\end{array}$} & \multicolumn{2}{|c|}{$\begin{array}{l}\text { Estimated amounts of } \\
\text { dissolved W. C (wt\%) }\end{array}$} & \multirow{2}{*}{$\begin{array}{l}\text { Conditions for heat } \\
\text { treatment }\end{array}$} \\
\hline & & & $\begin{array}{l}\text { By lattice } \\
\text { parameter }\end{array}$ & $\begin{array}{c}\text { By curie } \\
\text { point }\end{array}$ & \\
\hline $\begin{array}{l}\text { No. } 1 \text { in } \\
\text { Table } 3\end{array}$ & $\begin{array}{l}3.5571 \\
3.5630 \\
3.5545 \\
3.5523\end{array}$ & $\begin{array}{l}947 \\
964 \\
948 \\
946\end{array}$ & $\begin{array}{l}4 \\
6 \\
4 \\
3\end{array}$ & $\begin{array}{r}10 \\
9 \\
10 \\
10\end{array}$ & $\begin{array}{l}\text { As received after sintering } \\
\text { At } 980^{\circ} \mathrm{C} \text {, for } 5 \text { min water quenched } \\
\text { At } 780^{\circ} \mathrm{C} \text {, for } 1 \text { min furace cooled }\left(5^{\circ} \mathrm{C} / \mathrm{min}\right) \\
\text { At } 950^{\circ} \mathrm{C} \text {, for } 30 \text { min furnace cooled }\left(5^{\circ} \mathrm{C} / \mathrm{min}\right)\end{array}$ \\
\hline \multirow{2}{*}{$\begin{array}{l}\text { No. } 2 \text { in } \\
\text { Table } 3\end{array}$} & $\begin{array}{l}\text { (1) } 3.5759^{*} \\
\text { (2) } 3.570\end{array}$ & 883 & $\begin{array}{c}\text { (1) } 12^{*} \\
\text { (2) } 9 \\
\end{array}$ & 14 & As recived after sintering \\
\hline & $\begin{array}{l}\text { (1) } 3.5659^{*} \\
\text { (2) } 3.5496\end{array}$ & $\begin{array}{ll}(1) & 848 \\
\text { (2) } & 864 \\
\end{array}$ & $\begin{array}{ll}\text { (1) } & 8^{*} \\
\text { (2) } & 1 \\
\end{array}$ & $\begin{array}{ll}(1) & 15^{*} \\
\text { (2) } 14 \\
\end{array}$ & As $850^{\circ} \mathrm{C}$, for $1 \mathrm{hr}$ furnace cooled $\left(5^{\circ} \mathrm{C} / \mathrm{min}\right)$ \\
\hline $\begin{array}{l}\text { No. } 3 \text { in } \\
\text { Table } 3\end{array}$ & $\begin{array}{l}3.5491 \\
3.5567 \\
3.5479\end{array}$ & $\begin{array}{l}967 \\
963 \\
969\end{array}$ & $\begin{array}{l}2 \\
4 \\
1\end{array}$ & $\begin{array}{l}9 \\
9 \\
9\end{array}$ & $\begin{array}{l}\text { As received after sintering } \\
\text { At } 980^{\circ} \mathrm{C} \text {, for } 5 \mathrm{~min} \text { water quenched } \\
\text { At } 850^{\circ} \mathrm{C} \text {, for } 1 \mathrm{hr} \text { furnace cooled }\left(5^{\circ} \mathrm{C} / \mathrm{min}\right)\end{array}$ \\
\hline \multirow{2}{*}{$\begin{array}{l}\text { No. } 4 \text { in } \\
\text { Table } 3\end{array}$} & 3.5569 & 1010 & 4 & 6 & As raceived after sintering \\
\hline & $\begin{array}{l}\text { (1) } 3.5863^{*} \\
\text { (2) } 3.5806\end{array}$ & $\begin{array}{l}\text { (1) } 725^{*} \\
\text { (2) } 827\end{array}$ & $\begin{array}{l}\text { (1) } 13^{*} \\
(2) 11 \\
\end{array}$ & $\begin{array}{l}\text { (1) } 21^{*} \\
\text { (2) } 16 \\
\end{array}$ & At $1400^{\circ} \mathrm{C}$, for $30 \mathrm{~min}$ in air, water quenched \\
\hline
\end{tabular}

* two numerals were obtained from data which showed a mixture of two kinds of carbides.

Table 5 Miscellaneous examples of the results of hard alloys containing mixed carbides.

\begin{tabular}{|c|c|c|c|c|c|c|c|c|c|c|c|c|c|c|}
\hline \multirow[b]{2}{*}{$\begin{array}{c}\text { Speci- } \\
\text { men } \\
\text { No. }\end{array}$} & \multirow[b]{2}{*}{$4 \pi \sigma$} & \multirow[b]{2}{*}{$\begin{array}{l}\text { Curie } \\
\text { point } \\
\left({ }^{\circ} \mathrm{C}\right)\end{array}$} & \multirow[b]{2}{*}{$\begin{array}{l}\text { Lattice } \\
\text { para- } \\
\text { meter }\end{array}$} & \multicolumn{2}{|c|}{$\begin{array}{c}\text { Amount of } \delta \text { phase } \\
\text { (vol } \%)\end{array}$} & \multicolumn{5}{|c|}{$\begin{array}{c}\text { Chemical } \\
\text { compositions (wt \%) }\end{array}$} & \multirow{2}{*}{$\begin{array}{l}\text { Co \% } \\
\text { calcu- } \\
\text { lated } \\
\text { from } \\
4 \pi \sigma\end{array}$} & \multirow[b]{2}{*}{$\begin{array}{l}\text { Density } \\
\text { (g/cc) }\end{array}$} & \multirow[b]{2}{*}{$\begin{array}{c}\mathrm{RA} \\
\text { hardness }\end{array}$} & \multirow[b]{2}{*}{$\begin{array}{c}\text { T.R.S. } \\
\left(\mathrm{kg} / \mathrm{mm}^{2}\right)\end{array}$} \\
\hline & & & & $\underset{x-r a y}{\text { By }}$ & $\begin{array}{c}\text { Micro- } \\
\text { structure }\end{array}$ & $\begin{array}{l}\text { Total } \\
\text { carbon }\end{array}$ & $\begin{array}{l}\text { Free } \\
\text { carbon }\end{array}$ & Co & $\mathrm{Ti}$ & $\begin{array}{l}\mathrm{Ta}+\mathrm{Nb} \\
(\mathrm{Ta} \text { is } \\
\text { predomi- } \\
\text { nant }\end{array}$ & & & & \\
\hline 1 & 210 & 748 & 3.5460 & $\begin{array}{c}\text { large } \\
\text { amount }\end{array}$ & $\sim 3 \%$ & 5.59 & 0.01 & 1.25 & 5.0 & 5.0 & 10.4 & 13.07 & 88.9 & 一 \\
\hline 2 & 174 & 757 & 3.5460 & medium & $0.5 \sim 1 \%$ & 5.55 & 0.01 & 12.5 & 5.0 & 5.0 & 8.62 & 13.11 & 90.3 & - \\
\hline 3 & 280 & 972 & 3.5569 & - & - & 5.81. & 0.04 & 13 & 5.0 & 5.0 & 13.85 & 13.10 & 88.4 & 一 \\
\hline 4 & 213 & $\left(\begin{array}{l}823 \\
767\end{array}\right)$ & 3.5508 & $\begin{array}{c}\text { medium } \\
\text { a mount }\end{array}$ & $1 \sim 2 \%$ & 5.53 & 0.01 & 13 & 5.0 & 5.0 & 10.55 & 13.30 & 89.5 & 175 \\
\hline 5 & 218 & 1000 & 3.5499 & - & - & 6.22 & 0.01 & 10 & 14.0 & 5.5 & 10.80 & 12.88 & 90.3 & 195 \\
\hline 6 & 157 & $\left(\begin{array}{l}833 \\
770\end{array}\right)$ & 3.5496 & $\begin{array}{c}\text { small } \\
\text { amovnt }\end{array}$ & $0.1 \sim 0.5 \%$ & 5.99 & 0.01 & 10 & 14.0 & 5.5 & 7.78 & 12.80 & 90.3 & 167 \\
\hline 7 & 162 & 772 & 3.5448 & $\begin{array}{c}\text { medium } \\
\text { amount }\end{array}$ & $0.1 \sim 0.5 \%$ & 6.13 & 0.01 & 10 & 14.0 & 5.5 & 8.02 & 12.96 & 91.4 & 158 \\
\hline 8 & 136 & $\left(\begin{array}{l}735 \\
847\end{array}\right)$ & 3.5676 & ditto & $0.5 \sim 1 \%$ & 5.893 & 0.00 & 10 & 14.0 & 5.5 & 6.77 & 13.01 & 91.3 & 177 \\
\hline 9 & 184 & 928 & 3.5543 & - & - & 6.17 & 0.03 & 10 & 14.0 & 5.5 & 9.11 & 13.25 & 90.4 & 183 \\
\hline 10 & 204 & 952 & $\left(\begin{array}{l}3.5518 \\
3.5482\end{array}\right)$ & $-j$ & - & 6.15 & 0.01 & 10 & 14.0 & 5.5 & 10.10 & 12.95 & 91.0 & 166 \\
\hline 11 & 174 & $\left(\begin{array}{l}837 \\
767\end{array}\right)$ & 3.5482 & $\begin{array}{c}\text { medium } \\
\text { amount }\end{array}$ & $0.1 \sim 0.5 \%$ & 6.10 & 0.01 & 9.5 & 14.0 & 5.5 & 8.62 & 12.90 & 90.7 & 155 \\
\hline 12 & 164 & $\left(\begin{array}{l}813 \\
735\end{array}\right)$ & 3.5697 & - & - & 5.82 & 0.01 & - & 14.0 & 5.5 & 8.12 & 12.80 & 90.7 & 114 \\
\hline 13 & - & 888 & 3.5533 & $\begin{array}{c}\text { medium } \\
\text { amount }\end{array}$ & $0.5 \sim 1 \%$ & 6.50 & 0.08 & 6.2 & 5.0 & 3.12 & 一 & 12.78 & 92.8 & 130 \\
\hline 14 & " & 991 & 一 & - & $\sim 0.1 \%$ & 7.00 & 0.00 & 8.9 & 15.0 & 3.20 & " & 10.63 & 92.0 & 130 \\
\hline 15 & " & $\left(\begin{array}{l}945 \\
892\end{array}\right)$ & 3.5467 & 一 & - & 6.20 & 0.00 & 10 & 7.93 & 9.47 & $"$ & $11.99^{\circ}$ & 91.7 & 140 \\
\hline 16 & 187. & 996 & - & - & $\sim 0.05 \%$ & 6.22 & - & 9.3 & - & $\tau$ & 9.26 & 12.00 & 91.0 & - \\
\hline 17 & - & $\left(\begin{array}{l}765 \\
672\end{array}\right)$ & - & \begin{tabular}{|c|} 
medium \\
amount
\end{tabular} & $1 \sim 2 \%$ & - & - & - & - & - & - & 一 & - & - \\
\hline
\end{tabular}


alloys at room temperature could be purified by adequate heat-treatment below $1000^{\circ} \mathrm{C}$ and the Curie point was not influenced by the same treatment at all.

Table 5 shows some results of hard alloys containing mixed carbides. The values of the lattice parameter indicated that like the case of WC-Co hard alloys, the cobalt phase at room temperature could contain fairly large amounts of impurity atoms, in this case, carbon, tungsten, titanium, tantalum and niobium.

Curie point measurements showed that the range of temperature was much wider on the lower side in comparison with WC-Co alloys. In some alloys, two or three inflection-points on the magnetization-temperature curve were observed which could be attributed to the heterogeneity in the cobalt phase at high temperature.

\section{Discussion}

The cobalt phase in hard alloys of various grades and quality always have a face-centered cubic structure and a fairly large amount of impurity atoms may be dissolved in the solvent cobalt. The amount and type of solute seems to depend upon the manufacturing processes and compositions of the alloys, but they can be reduced by adequate heat-treatment below $1000^{\circ} \mathrm{C}$. The purity of the cobalt phase at room temperature may have some relation to the several characteristics and properties of the hard alloys, some examples are strength, hardness and others.

From a metallurgical point of view the Curie point of the cobalt phase can be regarded as a mark of purity at high temperature and is more important and determinate. Curie points of hard alloys are almost always

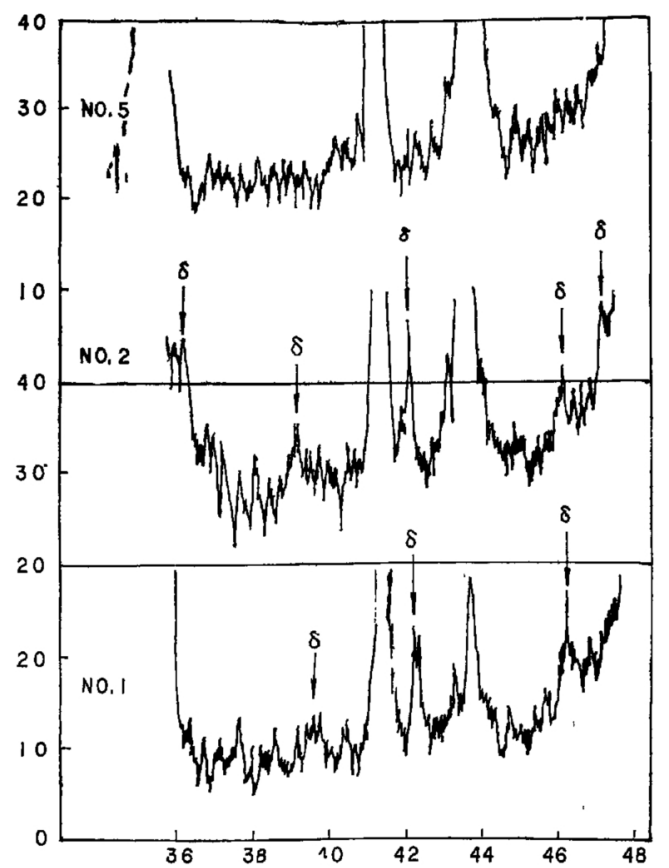

Fig. 6 X-ray diffraction pattern of hard alloys ; specimens are the same as in Photo. 2.

less than that of cobalt saturated with carbon. Photo. 2 shows a typical microstructure of a hard alloy with extraordinary characteristics in Curie point measurement, in which the $\delta$ phase is formed by a carbon deficiency. $\delta$ phases can also be verified by the $\mathrm{X}$-ray diffraction pattern as shown in Fig. 6 or by measure- ment of the magnetic saturation. The cobalt phase can solve various atoms as the temperature rises and the amount of metallic solute becomes larger, when the carbon content is deficient. According to this opinion, a certain amount of free carbon which is sufficient to saturate the cobalt phase is necessary to prevent any increase of metallic solute at high temperature.

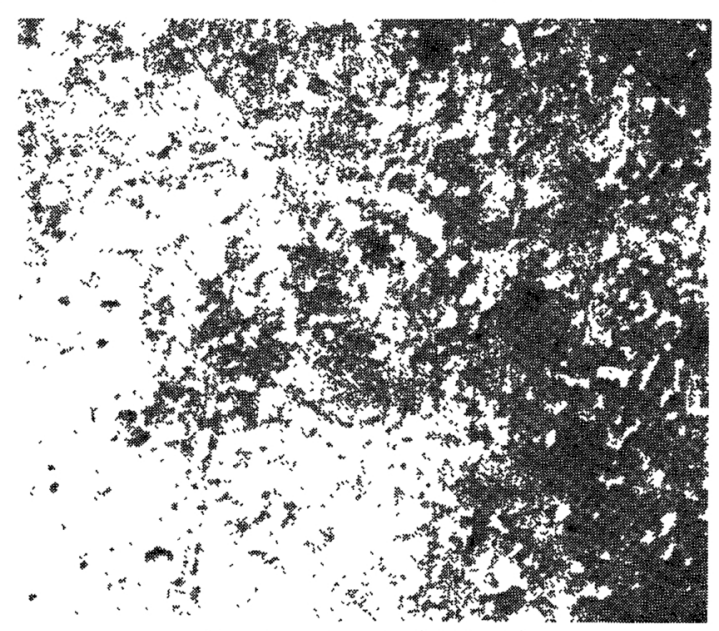

Specimen No. 5 (Table 5)

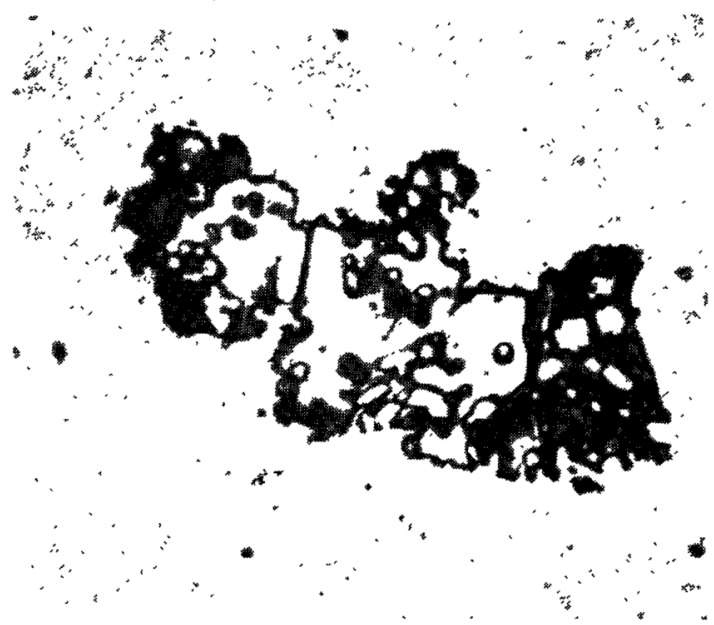

Specimen No. 2 (Table 5)

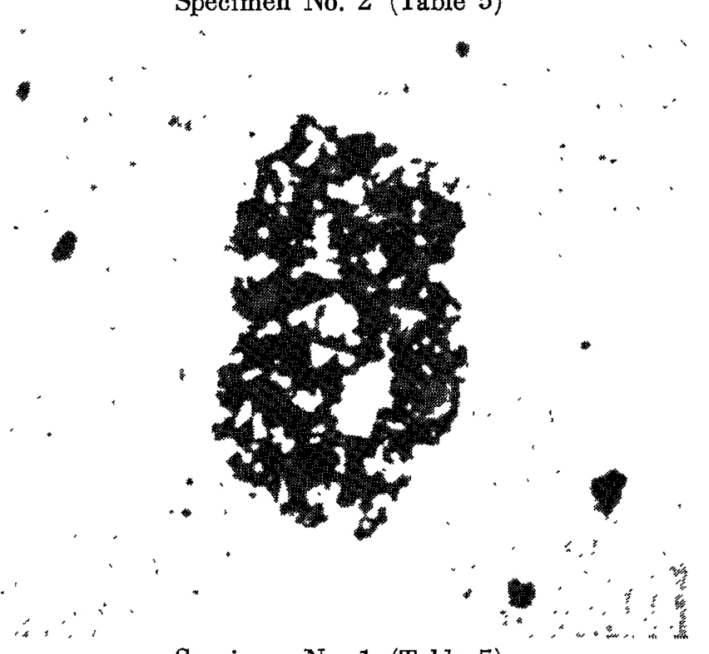

Photo. 2 Microstructure of $\mathrm{WC}^{-T i C}-\mathrm{Ta}(\mathrm{Nb}) \mathrm{C}$-Co hard alloys.

Potassium ferricyanide etching.

Magnification $=1500$

\section{Summary}

1. Cobalt alloys and commercial hard alloys were 
examined by $\mathrm{X}$-ray diffraction and Curie point measurement.

2. Tentative standards for the estimation of the quantities of solute atoms in the cobalt phase of hard alloys were obtained.

3. The cobalt phase in hard alloys always has a facecentered cubic structure.

4. Fairly large amounts of various atoms can be dissolved in the cobalt phase in hard alloys at room temperature.

5. The Curie point of the cobalt phase in hard alloys is always less than that of cobalt saturated with carbon. 6. The Curie point of the cobalt phase can be regarded as a mark of purity at high temperature.

7. The amount of metallic solute is large when the carbon content in the hard alloy is low. 